\title{
Antihypertensive and Antiproteinuretic Effects of Losartan in Spontaneously Hypertensive Rats with Chronic Renal Failure
}

\author{
Masahiro Kohzuki, Minoru Yasujima, Kazunori Yoshida, Masayuki Kanazawa, and Keishi Abe
}

\begin{abstract}
To assess the chronic antihypertensive and renal protective effects of losartan, a specific angiotensin II receptor antagonist, in the remnant kidney model of chronic renal failure, we administered losartan alone or in combination with enalapril, for 14 days to 5/6-nephrectomized spontaneously hypertensive rats (SHR). Eight-week-old SHR underwent 5/6 nephrectomy. One week after the operation, low-dose or high-dose losartan alone (1 or $10 \mathrm{mg} / \mathrm{kg} / \mathrm{day})$, or a combination of high-dose losartan and enalapril (6 $\mathrm{mg} / \mathrm{kg} / \mathrm{day}$ ) was administered intraperitoneally via an osmotic minipump for 14 days. Low-dose losartan only slightly attenuated the increase in blood pressure. High dose losartan completely blocked the increase in blood pressure throughout the experiment. Simultaneous administration of enalapril did not modify the antihypertensive effects of losartan. Furthermore, high-dose losartan with enalapril, and lowdose or high-dose losartan alone significantly decreased urinary protein excretion to the same extent. These effects were sustained for the entire experiment and were not associated with any significant changes in body weight, fluid intake, urine volume, urinary electrolyte excretion, or serum creatinine. These results suggest that losartan might have a renal protective effect independent of its systemic antihypertensive action. In addition, they suggest that the antihypertensive and renoprotective effects of ACE inhibitors in this rat model are mainly due to inhibition of angiotensin II production rather than to stimulation of the kallikrein-kinin system or the vasodilator prostaglandins. (Hypertens Res 1994; 17: 173-178)
\end{abstract}

Key Words: angiotensin II receptor antagonist, angiotensin converting enzyme inhibitor, enalapril, spontaneously hypertensive rat, nephrectomy

Systemic hypertension is a well-known cause of progressive renal injury in both humans and experimental animals $(1,2)$. In rats, a reduction of the functioning renal mass increases the systemic blood pressure and causes progressive renal failure. An increased filtration rate per glomerulus has been suggested to be responsible for the progressive deterioration of renal function $(3,4)$.

Antihypertensive therapy reduces the rate of decline of renal function in established progressive renal disease (5-7). Recent evidence suggests that the ability of antihypertensive therapy to protect the kidney relates largely to the glomerular hemodynamic consequences of therapy (8). Not all antihypertensive regimens afford equal renal protection, and agents that control glomerular hypertension may provide maximal protection to the kidney at risk for progressive glomerular injury $(8-10)$. Recently, angiotensin-converting enzyme inhibitors (ACEIs) have been shown to be beneficial against hyperfiltration damage in remnant kidney nephrons in chronic renal failure (11-13). However, ACEIs are nonspecific kininase inhibitors and have actions other than inhibition of the renin-angiotensin system. For example, ACEIs stimulate the kallikreinkinin system and vasodilator prostaglandins. A novel series of imidazole derivatives has been discovered and characterized as nonpeptide angiotensin II receptor antagonists (14-19). From this series, losartan has been identified as a potent, highly selective, and orally active angiotensin II receptor antagonist (19-21).

In the present study, to clarify the significance of the renin-angiotensin system in chronic renal failure, the ability of losartan to protect renal function was determined in nephrectomized spontaneously hypertensive rats (SHR).

\section{Methods}

Eight-week-old male SHR (Charles River Japan, Atsugi, Japan) underwent either 5/6 nephrectomy (removal of the left kidney and infarction of twothirds of the right kidney) (11) or a sham operation

From the Second Department of Internal Medicine, and Institute of Rehabilitation Medicine, Tohoku University School of Medicine, Sendai, Japan.

Address for Reprints: Masahiro Kohzuki, M. D., Ph. D., the Second Department of Internal Medicine, 1-1 Seiryo-cho, Aoba-ku, Sendai 980, Japan.

Received October 28, 1993; accepted in revised form May 17, 1994. 
Table 1. Preinfusion Data on Body Weight, Systolic Blood Pressure, Urine Volume, Urinary Protein Excretion, and Urinary Excretion of Sodium and Potassium in Spontaneously Hypertensive Rats with Chronic Renal Failure $(n=6$, each)

\begin{tabular}{lcccccc}
\hline & $\begin{array}{c}\mathrm{BW} \\
(\mathrm{g})\end{array}$ & $\begin{array}{c}\mathrm{SBP} \\
(\mathrm{mmHg})\end{array}$ & $\begin{array}{c}\mathrm{UV} \\
(\mathrm{ml} / \mathrm{day})\end{array}$ & $\begin{array}{c}\text { UproV } \\
(\mathrm{mg} / \mathrm{day})\end{array}$ & $\begin{array}{c}\mathrm{U}_{\mathrm{Na}} \mathrm{V} \\
(\mu \mathrm{Eq} / \mathrm{day})\end{array}$ & $\begin{array}{c}\mathrm{U}_{\mathrm{K}} \mathrm{V} \\
(\mu \mathrm{Eq} / \mathrm{day})\end{array}$ \\
\hline Vehicle & $159.8 \pm 4.9$ & $174.0 \pm 1.9$ & $26.8 \pm 3.6$ & $22.2 \pm 2.7$ & $980 \pm 98$ & $1,856 \pm 125$ \\
Losartan $(1 \mathrm{mg} / \mathrm{kg} /$ day $)$ & $162.2 \pm 5.0$ & $170.4 \pm 2.9$ & $25.6 \pm 3.8$ & $23.4 \pm 5.8$ & $730 \pm 53$ & $2,026 \pm 113$ \\
Losartan $(10 \mathrm{mg} / \mathrm{kg} /$ day $)$ & $167.0 \pm 7.7$ & $166.3 \pm 1.8$ & $20.3 \pm 2.0$ & $20.5 \pm 2.0$ & $852 \pm 78$ & $1,857 \pm 109$ \\
Losartan $(10 \mathrm{mg} / \mathrm{kg} /$ day $)$ & $160.8 \pm 6.8$ & $166.0 \pm 3.2$ & $21.0 \pm 2.2$ & $21.7 \pm 5.2$ & $864 \pm 36$ & $1,958 \pm 153$ \\
+ enalapril $(6 \mathrm{mg} \mathrm{kg} /$ day) & & & & & & \\
\hline
\end{tabular}

Results are expressed as means \pm SEM. BW, body weight; SBP, systolic blood pressure; UV, urine volume; UproV, urinary protein excretion; $U_{\mathrm{Na}} \mathrm{V}$, urinary sodium excretion; $\mathrm{U}_{\mathrm{K}} \mathrm{V}$, urinary potassium excretion.

(controls). One week after the 5/6 nephrectomy, each rat was housed in a metabolic cage designed to prevent feces-urine contact (Sugiyamagen, Tokyo, Japan) for collection of 24-hour urine samples. The rats were fed a standard rat chow (Funabashi Farm, Chiba, Japan) and had free access to tap water. Baseline systolic blood pressure, urine volume, urinary sodium and potassium excretion, and urinary protein excretion were measured. At 10 weeks of age, the rats were randomly allocated to receive losartan (2-n-butyl-4-chloro-5-hydroxymethyl-1-[(2' (1H-tetrazol-5-yl)biphenyl-4-yl) methyl] imidazole potassium salt) ( $n=6$, Banyu Pharmaceutical Co., Tokyo, Japan) $1 \mathrm{mg} / \mathrm{kg} /$ day alone, losartan 10 $\mathrm{mg} / \mathrm{kg} /$ day $(n=6)$ alone, a combination of losartan $10 \mathrm{mg} / \mathrm{kg} / \mathrm{day}$ and enalapril $6 \mathrm{mg} / \mathrm{kg} /$ day (Banyu Pharmaceutical Co., Tokyo, Japan $)(n=6)$ intraperitoneally via osmotic minipumps (model 2002, Alzet, Palo Alto, California, U. S. A.), or no treatment (vehicle alone, $n=6$ ) for 14 days. At the end of the experiment, the rats were killed by decapitation and trunk blood was collected in polyethylene tubes for the determination of serum creatinine.

Losartan and enalapril were dissolved in physiological saline before administration. All rats were maintained in a humidity- and temperature-controlled room during the study. Systolic blood pressure was recorded in conscious rats by the newly developed indirect tail cuff method (UEDA UR 1000, Ueda Industries Co., Tokyo, Japan) without anesthesia. The systolic blood pressure measured by this method correlates well with that measured directly (22). Daily water intake, urine volume, and body weight were gravimetrically measured. Urinary protein was measured by a colorimetric method (Tonein-TP,w Otsuka Pharmaceutical Co., Tokyo, Japan). Serum creatinine was measured with an auto-analyzer.

All results were expressed as means \pm SEM. With respect to the serum creatinine data, the different groups of rats were compared with the unpaired Student's $t$-test. For body weight, systolic blood pressure, urine volume, and urinary protein excretion data, the different groups of rats were compared with analysis of varience for repeated measures. Satistical significance of differences between groups on each day was assessed with the unpaired $t$-test. A $p$-value of less than 0.05 was considered significant.

\section{Results}

There were no significant differences in body weight, systolic blood pressure, water intake, urine volume, urinary sodium excretion, urinary potassium excretion, or urinary protein excretion between the groups before drug administration (Table 1).

Subtotal $(5 / 6)$ nephrectomy was well tolerated by all the rats. The average weight in each treated group was not significantly different from that in the control group during the study period [Control: $209.8 \pm 4.9 \mathrm{~g}$, losartan $1 \mathrm{mg} / \mathrm{kg} /$ day: $214.8 \pm 5.4 \mathrm{~g}$, losartan $10 \mathrm{mg} / \mathrm{kg} /$ day: $217.0 \pm 5.9 \mathrm{~g}$, losartan 10 $\mathrm{mg} / \mathrm{kg} /$ day with enalapril $6 \mathrm{mg} / \mathrm{kg} /$ day: $203.0 \pm 4.3$ $\mathrm{g}$, not significant (NS)].

Systolic blood pressure in the control group was $174 \pm 1.9 \mathrm{mmHg}$ at 10 weeks of age, and it rose progressively during the study (Fig. 1). At 12 weeks of age, systolic blood pressure in the control group was $222 \pm 3.0 \mathrm{mmHg}(p<0.01)$. Low-dose losar$\tan (1 \mathrm{mg} / \mathrm{kg} /$ day $)$ only slightly attenuated the increase in blood pressure (control vs. losartan 1 $\mathrm{mg} / \mathrm{kg} /$ day: $p<0.05)$. High-dose losartan (10 $\mathrm{mg} / \mathrm{kg} /$ day) completely blocked the increase in blood pressure throughout the experiment (control vs. losartan 10/mg/kg/day: $p<0.01$, losartan 1 $\mathrm{mg} / \mathrm{kg} /$ day $v s$. losartan $10 \mathrm{mg} / \mathrm{kg} /$ day: $p<0.01$ ). Low-dose and high-dose losartan and losartan with enalapril attenuated the increase in blood pressure, and the antihypertensive effects of these regimens continued throughout the experimental period. Systolic blood pressure tended to be lower in the losartan-with-enalapril group than in the losartanonly groups, but the differences were not significant.

Urinary protein excretion in the control group was $20.1 \pm 2.5 \mathrm{mg} /$ day at 10 weeks of age, and it rose progressively during the study (Fig. 2). At 12 weeks of age, urinary protein excretion in the control group was $57.5 \pm 13.2 \mathrm{mg} /$ day $(p<0.01)$. Losartan and losartan with enalapril attenuated the increase in urinary protein excretion; this effect continued throughout the experiment (ANOVA $p<$ 0.05 for all three comparisons). Although losartan dose-dependently decreased systolic blood pressure, the two losartan dosages decreased urinary protein 
excretion to the same extent. Furthermore, urinary protein excretion tended to be lower in the losartan-with-enalapril group than in the losartan only groups, although the differences were not significant.

Losartan and losartan with enalapril did not affect urine volume or urinary sodium and potassium excretion (Figs. 3-5). Urine volume, urinary sodium and potassium excretion, and urinary protein excretion on the first day of the infusion tended to be

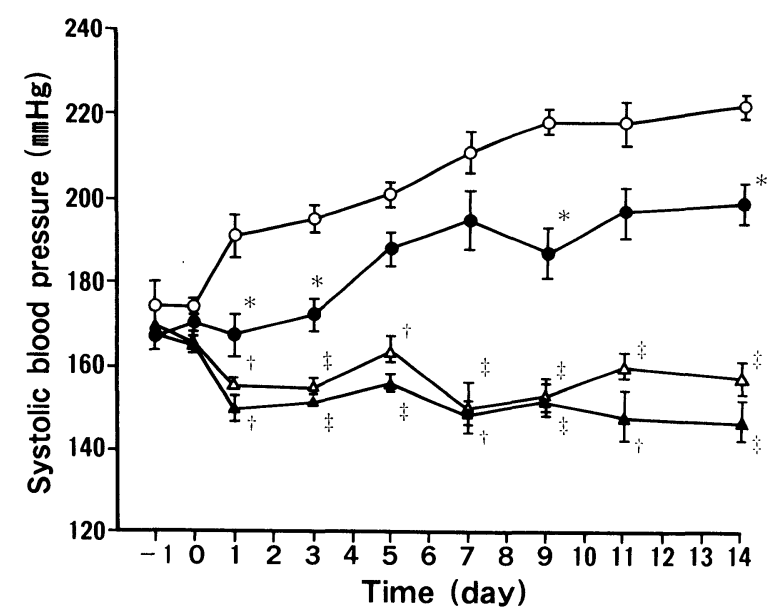

Fig. 1. Line graph showing sequential systolic blood pressure values in spontaneously hypertensive rats with chronic renal failure. Rats received vehicle (control) $(\bigcirc)$, losartan $1 \mathrm{mg} / \mathrm{kg} /$ day (O), losartan $10 \mathrm{mg} / \mathrm{kg} /$ day $(\triangle)$, or a combination of losartan $10 \mathrm{mg} / \mathrm{kg} /$ day and enalapril 6 $\mathrm{mg} / \mathrm{kg} /$ day (A). Data points are means \pm SEM. Analysis of variance for repeated measures revealed a significant change in systolic blood pressure in rats that received losartan $1 \mathrm{mg} / \mathrm{kg} /$ day, losartan $10 \mathrm{mg} / \mathrm{kg} /$ day, and the combination of losartan $10 \mathrm{mg} / \mathrm{kg} /$ day and enalapril 6 $m g / k g /$ day $(\mathrm{p}<0.01)$, as compared with the control group. ${ }^{*} \mathrm{p}<0.05,{ }^{\dagger} \mathrm{p}<0.01,{ }^{\ddagger} \mathrm{p}<0.001$ compared with control. low, probably because of the operation and the anesthesia. However, there were no significant differences among the 4 groups in these parameters.

There were no significant differences in serum creatinine among the four groups (Control: $0.73 \pm$ $0.04 \mathrm{mg} / \mathrm{dl}$, losartan $1 \mathrm{mg} / \mathrm{kg} /$ day: $0.78 \pm 0.21$ $\mathrm{mg} / \mathrm{dl}$, losartan $10 \mathrm{mg} / \mathrm{kg} / \mathrm{day}: 0.65 \pm 0.08 \mathrm{mg} / \mathrm{dl}$, losartan $10 \mathrm{mg} / \mathrm{kg} /$ day with enalapril $6 \mathrm{mg} / \mathrm{kg} /$ day: $0.74 \pm 0.11 \mathrm{mg} / \mathrm{dl}, \mathrm{NS})$.

\section{Discussion}

In the present study we evaluated the hemodynamic and renal effects of a specific angiotensin II receptor antagonist, losartan, in rats with a remnant kidney model of chronic renal failure. We also studied the effects of losartan with enalapril in this model. The data clearly show that losartan dose-dependently decreased systolic blood pressure. Furthermore, losartan both alone and in combination with enalapril attenuated the development of hypertension to the same extent and decreased urinary protein excretion.

The mechanism by which ACEI lowers systemic blood pressure is not well understood. The inhibition of angiotensin II formation and increases in the levels of kinins and vasodilator prostaglandins may be mainly responsible for the hypotensive effect (23-25). In contrast, losartan does not potentiate the vasodilatory activity of kinins, and its antihypertensive activity is unaffected by prostaglandin synthesis inhibition (19-21). In the present study, enalapril did not modify the antihypertensive effect of losartan. The present results suggest that the antihypertensive effects of an ACE inhibitor in this rat model are mainly due to inhibition of angiotensin II production.

A model combining SHR with reduced renal mass was chosen because the functional and structural nephropathy is known to develop faster than in a normotensive model with reduced renal mass (26). This model produces increases in hydraulic

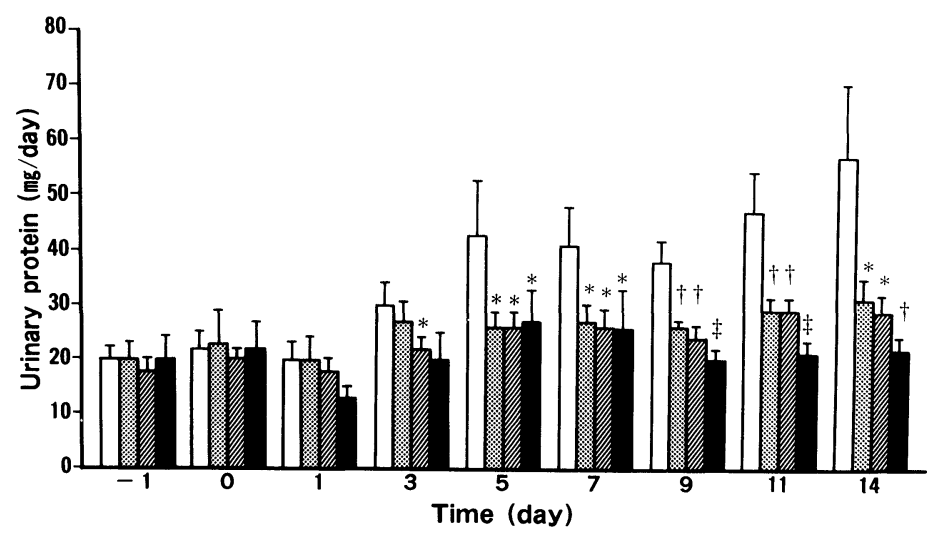

Fig. 2. Column graph showing sequential values of urinary protein excretion in spontaneously hypertensive rats with

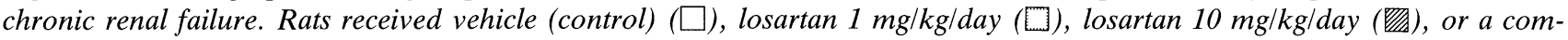
bination of losartan $10 \mathrm{mg} / \mathrm{kg} /$ day and enalapril $6 \mathrm{mg} / \mathrm{kg} /$ day $(\mathbf{\square})$. Data points are means $\pm S E M$. Analysis of variance for repeated measures revealed a significant change in urinary protein excretion in rats that received losartan $1 \mathrm{mg} / \mathrm{kg} /$ day, losartan $10 \mathrm{mg} / \mathrm{kg} /$ day, and the combination of losartan $10 \mathrm{mg} / \mathrm{kg} /$ day and enalapril $6 \mathrm{mg} / \mathrm{kg} /$ day $(\mathrm{p}<0.01$, as compared with the control group). ${ }^{*} \mathrm{p}<0.05,{ }^{\dagger} \mathrm{p}<0.01$ and ${ }^{\ddagger} \mathrm{p}<0.001$ compared with control. 


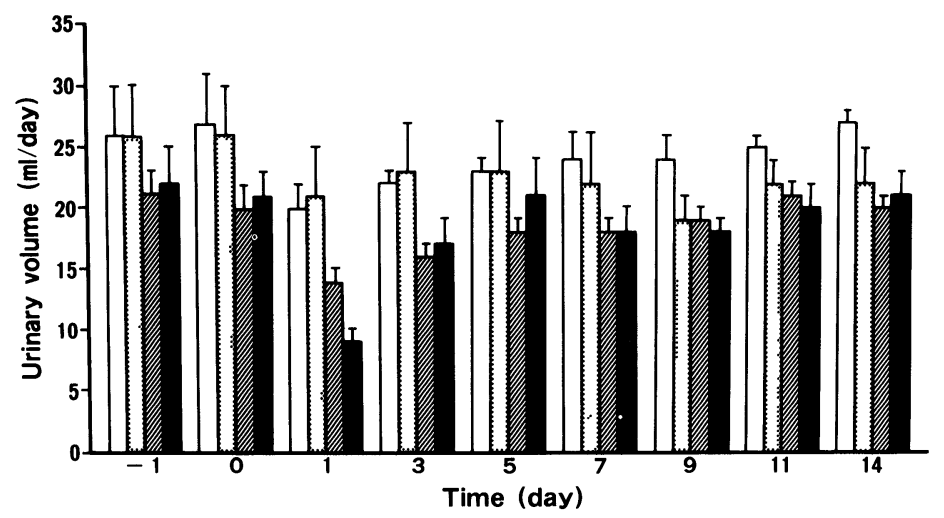

Fig. 3. Column graph showing sequential values of urine volume in spontaneously hypertensive rats with chronic renal

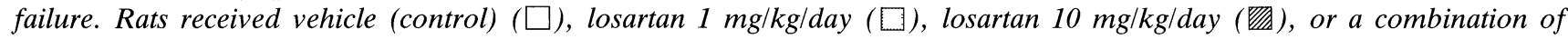
losartan $10 \mathrm{mg} / \mathrm{kg} /$ day and enalapril $6 \mathrm{mg} / \mathrm{kg} /$ day (ם). Data points are means $\pm S E M$. Analysis of variance for repeated measures revealed no significant change in urine volume in any of the four groups.

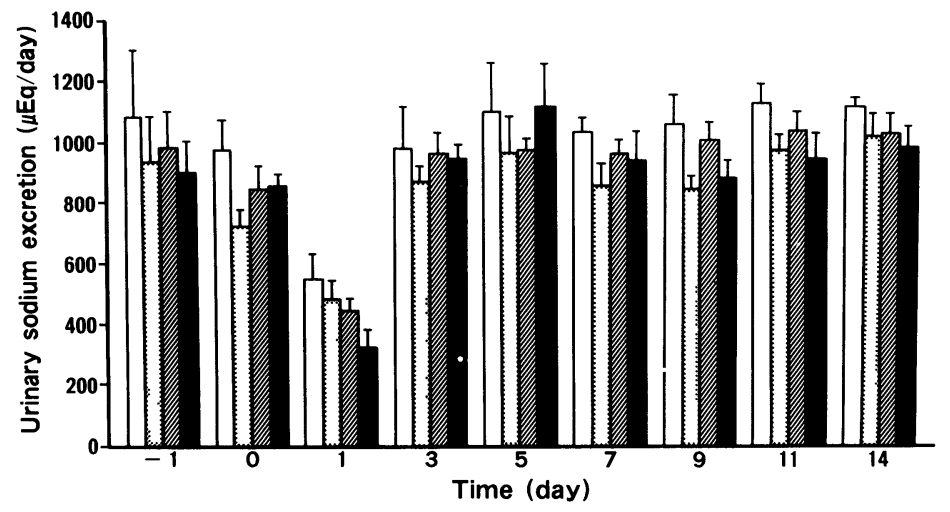

Fig. 4. Column graph showing sequential values of urinary sodium excretion in spontaneously hypertensive rats with

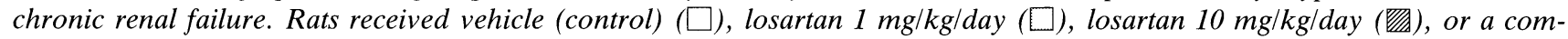
bination of losartan $10 \mathrm{mg} / \mathrm{kg} /$ day and enalapril $6 \mathrm{mg} / \mathrm{kg} /$ day (耳). Data points are means $\pm S E M$. Analysis of variance for repeated measures revealed no significant change in urinary sodium excretion in any of the four groups.

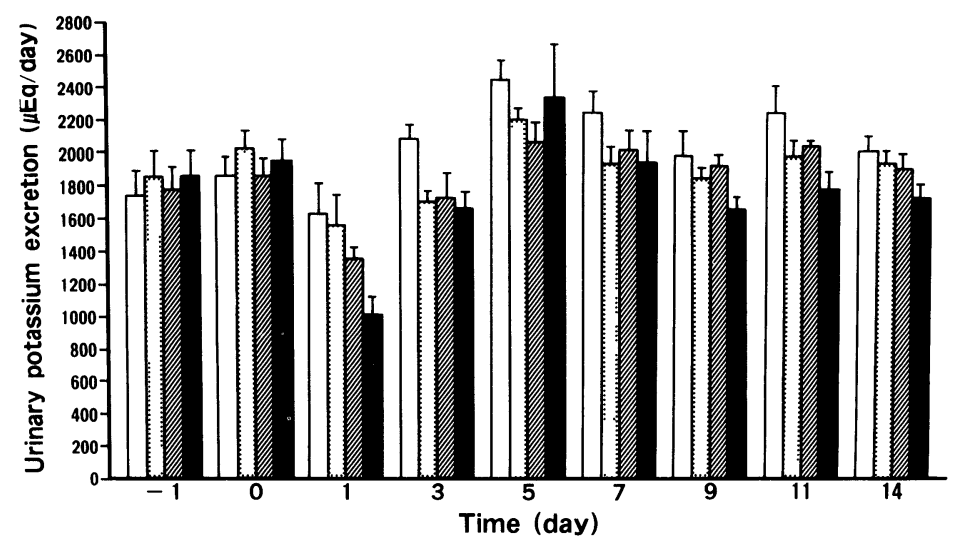

Fig. 5. Column graph showing sequential values of urinary potassium excretion in spontaneously hypertensive rats with

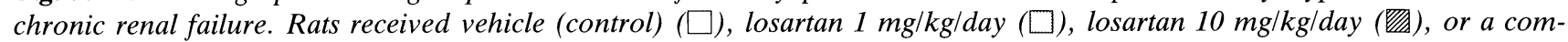
bination of losartan $10 \mathrm{mg} / \mathrm{kg} /$ day and enalapril $6 \mathrm{mg} / \mathrm{kg} /$ day ( $\mathbf{\square})$. Data points are means $\pm S E M$. Analysis of variance for repeated measures revealed no significant change in urinary potassium excretion in any of the four groups. 
pressure and in plasma flow rate, in association with an increase in single nephron GFR $(3,4)$.

In our previous study (27), treatment with ACEIs (captopril, ramipril) or calcium channel blockers (nilvadipine, benidipine) for twelve weeks in a similar rat model induced a significant reduction in systolic blood pressure of the same degree. Despite the similar antihypertensive effects, deterioration of renal function and structure in this model was prevented by treatment with the ACEI, but not by treatment with calcium channel blockers. Intrarenal glomerular capillary hypertension can be dissociated from, and may be more important than, systemic hypertension per se in the pathogenesis of glomerular injury.

In the present study, proteinuria progressively increased in nephrectomized SHR, which is consistent with the development of hypertension. However, two weeks was not enough time to cause marked structural changes in the kidney in preliminary experiments. Therefore, in the present study we did not examine the kidneys histologically.

In the present study, low-dose losartan (1 $\mathrm{mg} / \mathrm{kg} /$ day) only slightly attenuated the increase in blood pressure. High-dose losartan $(10 \mathrm{mg} / \mathrm{kg} / \mathrm{day})$ completely blocked the increase in blood pressure throughout the experiment. However, the two losartan dosages decreased urinary protein excretion to the same extent. These results indicate that losartan could have a renal protective effect independent of its antihypertensive action. Losartan might preferentially lessen intra-glomerular hypertension rather than systemic hypertension. Bovee et al. (28) reported that the renal effects of losartan occurred at doses lower than necessary to reduce arterial pressure in spontaneously hypertensive pulmonary hypertensive dogs. This finding may indicate that the kidneys are more sensitive than the peripheral vasculature to blockade of angiotensin II receptors by losartan.

The mechanism underlying the renoprotective effects of losartan and enalapril may be a reduction in intraglomerular capillary pressure. Although we could not assess intraglomerular hyperfiltration in these experiments, angiotensin II is known to constrict the efferent arterioles, and thus to help maintain glomerular capillary pressure and glomerular filtration $(9,11,29)$. Removal of angiotensin II by ACEIs or inhibition of its activity by losartan would reduce capillary pressure and glomerular filtration. Recently, Lafayette et al. reported data from a micropuncture study, which showed that losartan and enalapril were equally effective in reducing systemic and glomerular transcapillary pressure in rats after renal ablation (30).

In addition to efferent vasoconstriction, angiotensin II has many other actions in the kidney, including effects on mesangial cell contraction and macromolecular uptake through the mesangium (31), glomerular permeability to proteins (32), tubular sodium reabsorption (33), and vasa recta blood flow (34), all of which might modulate the progression of intrarenal pathology in renal failure. Therefore, ACEI-induced inhibition of the production of angiotensin II or inhibition of the activity of angiotensin II by losartan may cause many changes other than those seen in glomerular hemodynamic variables, some of which may contribute to the renal protective effects of ACEIs.

The effects of losartan may be more apparent in rats in which the renin-angiotensin system is activated by salt depletion (35). However, in a preliminary study, rats fed a low-sodium diet did not gain weight and reduced their food and water intake. Therefore, we did not try to administer a lowsodium diet in the present experiment.

Angiotensin II regulates proximal tubular reabsorption of sodium (33), perhaps by stimulating sodium-hydrogen exchange in this portion of the nephron. However, in the present study, neither losartan nor. losartan with enalapril affected body weight, water intake, urine volume, or urinary sodium and potassium excretion. We have no unequivocal explanation for these findings. The distal nephron in these animals might have fully compensated for changes in the proximal reabsorption of sodium and water. It is also possible that the sodium retention associated with the fall in renal perfusion pressure was sufficient to counteract the natriuretic effect of renal angiotensin II receptor blockade. Furthermore, the present findings do not contradict previous studies indicating that angiotensin II plays an important role in the control of renal hemodynamics and sodium excretion, because most previous studies were done with animals in which the renin-angiotensin system was activated by salt depletion (28). The lack of natriuretic effect of losartan in rats with reduced renal mass is consistent with the previous results indicating that blockade of the renin-angiotensin system has little effect on sodium and water excretion in salt-replete animals $(21,36)$.

In summary, losartan dose-dependently decreased systolic blood pressure. Furthermore, losartan both alone and in combination with enalapril similarly attenuated the development of hypertension, and decreased urinary protein excretion in SHR with reduced renal mass. These results indicate that losartan may have a renal protective effect independent of its antihypertensive action. In addition, they suggest that the antihypertensive and renoprotective effects of ACEIs in this rat model are largely due to inhibition of angiotensin II production rather than to stimulation of the kallikrein-kinin system and vasodilator prostaglandins.

\section{Acknowledgments}

We are grateful to Banyu Pharmaceutical Co., Tokyo, Japan for supplying losartan and enalapril. This work was supported by Grants-in-Aid from the Japanese Foundation for Cardiovascular Research, and for scientific research from the Ministry of Education, Science and Culture of Japan (06670689).

\section{References}

1. Kimura G, Brenner BM: A method for distinguishing 
salt-sensitive from non-salt-sensitive forms of human and experimental hypertension. Curr Opin Nephrol Hypertens 1993; 2: 341-319.

2. Anderson S, Brenner BM: The critical role of nephron mass and of intraglomerular pressure for initiation and progression of experimental hypertensive-renal disorders, in Laragh $\mathrm{JH}$, Brenner BM (eds): Hypertension; Pathophysiology, Diagnosis and Management. New York, Raven Press, 1990, pp 1163-1176.

3. Hostetter TH, Olson JH, Rennke HG, et al: Hyperfiltration in remnant nephrons: a potentially adverse response to renal ablation. Am J Physiol 1981; 241: F85-F93.

4. Brenner BM: Nephron adaptation to renal injury or ablation. Am J Physiol 1985; 249: F324-F339.

5. Bedogna V, Valvo E, Casagrande P, et al: Effects of ACE inhibition in normotensive patients with chronic glomerular disease and normal renal function. Kidney Int 1990; 38: 101-107.

6. Parving H, Anderson A, Smidt U, Svendsen P: Early aggressive anti-hypertensive treatment reduces rate of decline in kidney function in diabetic nephropathy. Lancet 1983; i: 1176-1179.

7. Parving $\mathrm{H}$, Anderson A, Smidt U, Hommel E, Mathiesen E, Svendsen P: Effect of antihypertensive treatment on kidney function in diabetic nephropathy. Br Med J 1987; 294: 1443-1447.

8. Anderson S, Rennke HG, Garcia DL, Brenner BM: Short and long term of antihypertensive therapy in the diabetic rat. Kidney Int 1989; 36: 526-536.

9. Anderson S, Rennke HG, Brenner BM: Therapeutic advantage of converting enzyme inhibitors in arresting progressive renal disease associated with systemic hypertension in the rat. J Clin Invest 1986; 77: 1993-2000.

10. Beukers JJB, Van der Wal A, Hoedemaeker PJ, Weening JJ: Converting enzyme inhibition and progressive glomerulosclerosis in the rat. Kidney Int 1987; 32: 794-800.

11. Anderson S, Meyer TW, Rennke HG, et al: Control of glomerular hypertension limits glomerular injury in rats with reduced renal mass. $J$ Clin Invest 1985; 76: $612-619$.

12. Tolins JP, Raij L: Angiotensin converting enzyme inhibitors and progression of chronic renal failure. Kidney Int 1990; 38 (suppl 30): 118-122.

13. Meyer TW, Anderson S, Rennke HG, et al: Converting enzyme inhibitor therapy limits progressive glomerular injury in rats with renal insufficiency. $A m J$ Med 1985; 79 (suppl 3C): 31-36.

14. Wong PC, Chiu AT, Price WA, et al: Nonpeptide angiotensin II receptor antagonists I. Pharmacological characterization of 2-n-butyl-4-chloro-1-(2-chlorobenzyl) imidazole-5-acetic acid, sodium salt (S8307). J Pharmacol Exp Ther 1988; 247: 1-7.

15. Hsieh K, Marshall GR: Role of the C-terminal carboxylate in angiotensin II: Alcohol, ketone and ester analogs of angiotensin II. J Med Chem 1986; 29: 1968-1971.

16. Chiu AT, Duncia JV, McCall DE, et al: Nonpeptide angiotensin II receptor antagonists. III. Structurefunction studies. J Pharmacol Exp Ther 1989; 250: 867-875.

17. Wong PC, Price WA, Chiu AT, et al: Nonpeptide angiotensin II receptor antagonists. IV. EXP6155 and EXP6803. Hypertension 1989; 13: 489-497.

18. Timmermans PBMWM, Carini DJ, Chiu AT, et al: Angiotensin II receptor antagonists: from discovery to antihypertensive drugs. Hypertension 1991; 18: III136-III-142.
19. Wong PC, Price WA, Chiu AT, et al: Nonpeptide angiotensin II receptor antagonists: studies with EXP 9270 and DuP753. Hypertension 1990; 15: 823-834.

20. Wong PC, Price WA, Chiu AT, et al: Nonpeptide angiotensin II receptor antagonists. VIII. Characterization of functional antagonism displaced by DuP753, an orally active antihypertensive agent. $J$ Pharmacol Exp Ther 1990; 252: 719-725.

21. Timmermans PBMWM, Wong PC, Chiu AT, et al: Nonpeptide angiotensin II receptor antagonists. TIPS 1991; 12: 55-62.

22. Ikeda K, Nara Y, Yamori Y: Indirect systolic and mean blood pressure determination by a new tail cuff method in spontaneously hypertensive rats. Labo Animals 1991; 25: 26-29.

23. Carretero OA, Scicli AG: Kinins paracrine hormone. Kidney Int 1988; 34: s52-s59.

24. Beierwaltes WH, Carretero OA: Kinin antagonist reverses converting enzyme inhibitor-stimulated vascular prostaglandin $\mathrm{I}_{2}$ synthesis. Hypertension $1989 ; 13$ : 754-758.

25. Danckwardt L, Shimizu I, Bonner R, et al: Converting enzyme inhibition in kinin-deficient brown Norway rats. Hypertension 1990; 16: 429-435.

26. Raij L, Chiou X, Owens $\mathrm{R}$, et al: Therapeutic implications of hypertension induced glomerular injury. Comparison of enalapril and a combination of hydralazine, reserpine and hydrochlorothiazide in an experimental model. Am J Med 1985; 79 (suppl 3C): 37-41.

27. Kohzuki M, Yasujima M, Kanazawa M, et al: Angiotensin converting enzyme inhibitors and progression of chronic renal failure in rats with reduced renal mass. in MacGregor GA, Sever PS (eds): Proceedings of Asian-Pacific Symposium of ACE inhibition Macclesfield, Gardiner-Caldwell Communications Ltd., 1993 pp 63-67.

28. Bovee KC, Wong PC, Timmermans PBMWM, Thoolen JMC: Effects of nonpeptide angiotensin II receptor antagonist DuP 753 on blood pressure and renal functions in spontaneously hypertensive $\mathrm{PH}$ dogs. Am J Hypertens 1991; 4: 327s-333s.

29. Keane WF, Anderson S, Aurell M, De Zeeuw D, Narins R, Povar C: Angiotensin converting enzyme inhibitors and progressive renal insufficiency - current experience and future directions. Ann Intern Med 1989; 111: 503-516.

30. Lafayette RA, Mayer G, Park SK, et al: Angiotensin II receptor blockade limits glomerular injury in rats with reduced renal mass. J Clin Invest 1992; 90: 766-771.

31. Raij L, Keane WF: Glomerular mesangium; Its function and relationship to angiotensin II. Am J Med 1985; 79 (suppl 3C): 24-30.

32. Remuzzi A, Puntorieri S, Battaglia C, Bertani T, Remuzzi G: Angiotensin converting enzyme inhibition ameliorates glomerular filtration of macromolecules and water and lessens glomerular injury in the rat. $J$ Clin lnvest 1990; 85: 541-549.

33. Hall JE: Regulation of glomerular filtration and sodium excretion by angiotensin II. Fed Proc 1986; 45: 1431-1437.

34. Chou S-Y, Faubert PF, Porush JG: Contribution of angiotensin to the control of medullary haemodynamics. Fed Proc 1986; 45: 1438-1443.

35. Hall JE, Guyton AC, Smith MJ, et al: Chronic blockade of angiotensin II formation during deprivation. Am J Physiol 1986; 250: R960-R972.

36. Hall JE, Guyton AC, Jackson TE, et al: Control of glomerular filtration rate by renin-angiotensin system. Am J Physiol 1977; 233: F366-F372. 